\title{
PENGUASAAN 4 (EMPAT) PRASYARAT DASAR ARITMATIKA UNTUK MENINGKATKAN KEMAMPUAN SISWA SEKOLAH DASAR DALAM MENYELESAIKAN SOAL MATEMATIKA
}

\section{MASTERING 4 (FOUR) BASIC PROCEDURES OF ARITHMATICS TO IMPROVE BASIC SCHOOL STUDENTS 'ABILITY IN COMPLETING MATHEMATICS PROBLEMS}

\author{
ENDRO TRI SUSDARWONO \\ Program Studi IlmuKomunikasi, UniversitasPeradabanBrebes \\ Jalan Pagojengan KM 3 PaguyanganBrebes' email: midas999saniscara@gmail.com
}

\begin{abstract}
Abstrak
Tujuan penelitian ini membahas mengenai bagaimana penguasaan 4 (empat) prasyarat dasar aritmatika yang meliputi kemampuan membilang, membuat barisan bilangan aritmatika/kelipatan, komplemen terutama sembilan dan sepuluh, dan konsep nilai tempat pada bilangan mempengaruhi kemampuan siswa dalam menyelesaikan soal matematika yang terdiri atas penjumlahan, pengurangan, perkalian, dan perkalian. Pendekatan dalam penelitian ini menggunakan pendekatan deskriptif, metode yang digunakan adalah metode kombinasi antara kualitatif dan kuantitatif. Pendekatan kualitatif digunakan untuk mendeskripsikan tentang penguasaan aritmatika dasar siswa meliputi kemampuan membilang, membuat barisan bilangan Aritmatika/ kelipatan, komplemen terutama sembilan dan sepuluh, dan konsep nilai tempat pada bilangan. Adapun pendekatan kuantitatif menggunakan uji statistic dengan analisis korelasi kanonikal untukmenjawab tentang hubungan dan pengaruh antara pemahaman tentang penguasaan aritmatika dasar terhadap kemampuan menyelesaikan soal matematika terkait penjumlahan, pengurangan, perkalian dan pembagian. Dari hasil canonical weight maupun canonical loading fungsi 1 dapat disimpulkan memang terdapathubungan signifik antara dependent variate dengan independent variate atau penguasaan aritmatika dasar dan kemampuan siswa dalam mengerjakan soal matematika memang berkorelasi secara bersama-sama.
\end{abstract}

Kata kunci : aritmatika, prasyaratdasar, soalmatematika

\begin{abstract}
The purpose of this study discusses how mastery of 4 (four) basic prerequisites of arithmetic which includes the ability to count, make Arithmetic / multiples, complement especially Nines and ten, and the concept of place values in numbers affect students' ability to solve math problems consisting of addition, subtraction, multiplication, and multiplication. The approach in this study uses a descriptive approach, the method used is a combination of qualitative and quantitative methods. A qualitative approach is used to describe the basic arithmetic mastery of students including numeracy, making Arithmetic / multiples numbers, complements especially nines and ten, and the concept of place values in numbers. The quantitative approach uses statistical tests with canonical correlation analysis to answer the relationship and influence between understanding of basic arithmetic mastery on the ability to solve math problems related to addition, subtraction, multiplication and division. From the results of the canonical weight and canonical loading function 1 , it can be concluded that there is indeed a significant relationship between the dependent variate and the independent variate or basic arithmetic mastery and the students' ability to do math problems is indeed correlated together.
\end{abstract}

Key Words : arithmetic, basic prerequisites, math problems 
$\mathrm{Hal}: 72-84$

\section{Pendahuluan}

Keterkaitan erat antara pendidikan dan matematika adalah terutama dalam bidang perkembangan ilmu pengetahuan dan teknologi. Matematika merupakan cabang ilmu yang penting yang perlu diberikan pemahamann dan penguasaan terhadap semua lapisan masyarakat utamanya di sekolah [1]. Pemahaman dan penguasaan terhadap matematika itu harus diawali dari yang mudah, sedang, hingga sulit dikarenakan matematika merupakan ilmu terstruktur, dalam matematika terdapat banyak konsep yang saling terkait antara konsep yang satu dengan yang lainnya. Koneksi matematis harus dimiliki siswa dalam memahami pemahaman konsep secara mendalam[2].

Akal atau rasio merupakan modal dasar dalam menguasai matematika disebabkan bidang ilmu ini pada hakikatnya merupakan suatu ilmu yang berhubungan benda-benda dalam pikiran yang abstrak atau matematika memiliki objek kajian yang abstrak [3]. Seperti yang kita ketahui bahwa matematika merupakan matapelajaran wajib yang ditempuh disetiap jenjang pendidikan. Dalam matematika diajarkan untuk bersikap teliti, ulet, dan berpikir secara disiplin sehingga dengan belajar matematika akan mempengaruhi pola berpikir siswa. Namun dalam kenyataan tidak semua siswa mampu memahami dengan mudah, masih terdapat siswa yang kesulitan dalam belajar matematika karena pada diri mereka masih tertanam anggapan bahwa matematika adalah matapelajaran yang menakutkan[4].

Pembelajaran terhadap matematika memerlukan tingkat berpikir yang tinggi, sehingga terhadap siswa yang memiliki anggapan bahwa matematika sulit dan membosankan diperlukan metode tertentu dalam pembelajaran mattematika. Untuk meningkatkan kemampuan daya berpikir matematis yang lebih rumit atau tingkat tinggi, siswa perlu membiasakan diri dalam memecahkan masalahmasalah kontekstual non rutin [5].

Russeffendi [6] mengungkapkan bahwa siswa masih menggangap matematika sebagai ilmu yang sukar dan rumit yang mengakibatkan hasil belajar matematika siswa pada umumnya masih rendah.Banyak faktor yang mempengaruhi keadaan siswa tersebut, seperti yang diungkapkan bahwa ada sepuluh faktor yang mempengaruhi keberhasilan siswa dalam belajar antara lain: kecerdasan, kesiapan belajar, bakat, kemauan belajar, minat, cara penyajian materi pembelajaran, pribadi dan sikap pengajaran, suasana pengajaran, kompetensi pengajar, dan kondisi masyarakat luas.Berdasarkan faktor yang dikemukakan oleh Russeffendi disebutkan salah satu yang mempengaruhi kondisi siswa adalah cara penyajian materi pembelajaran.

Afgani (2011) menyatakan bahwa koneksi matematis didasarkan pada matematika sebagai ilmu yang terstruktur dan terdiri dari bagian-bagian yang saling berhubungan [7]. Terdapat 4 (empat) prasyarat dasar aritmatika yang sebaiknya dimiliki anak atau siapapun agar dapat menyelesaikan semua persoalan ilmu hitung dengan lebih mudah dan praktis terkait pelajaran matematika. Empat prasarat dasar itu meliputi: kemampuan membilang, membuat barisan bilangan Aritmatika/kelipatan, komplemen terutama sembilan dan sepuluh, dan konsep nilai tempat pada bilangan. Operasi hitung yang lebih rumit akan menjadi terasa lebih mudah apabila anak atau siapapun menguasai empat prasyarat dasar ini[8].

Keterampilan membilang maju akan membantu anak menyelesaikan soal penjumlahan dengan lancar, sedangkan keterampilan membilang mundur membantu anak menyelesaikan soal pengurangan. Keterampilan ideal yang sebaiknya dilatih untuk membilang maju dan mundur adalah sampai 18 (delapan belas). Semua operasi penjumlahan dan pengurangan termasuk teknik hitung yang diajarkan disekolah bisa dilakukan dengan jauh lebih mudah dan cepat, apabila anak mahir membilang maju dan mundur sampai 18 karena dalam operasi hitung standar yaitu operasi hitung basis 10, bilangan 18 adalah penjumlahan angka satuan terbesar yaitu $9+9$.

Keterampilan membuat barisan bilangan kelipatan adalah dasar konsep perhitungan yang penting yang nantinya akan berguna saat anak menghitung perkalian dan pembagian. Perkalian pada dasarnya adalah penjumlahan berulang. Sedangkan pembagian adalah pengurangan berulang. Terkait komplemen terutama Sembilan dan sepuluh, komplemen ini merupakan komplemen terpenting yang sebaiknya diajarkan. Komplemen Sembilan penting karena Sembilan adalah angka satuan terbesar dan memiliki sifat-sifat yang cukup istimewa. Beberapa kasus perkalian misalnya perkalian istimewa angka Sembilan, juga bisa dihitung dengan mudah apabila anak terampil memakai komplemen Sembilan. Komplemen sepuluh juga penting karena perhitungan standar yang kita lakukan adalah memakai basis sepuluh. Sedangkan Konsep nilai tempat pada bilangan adalah konsep yang penting yang sebaiknya diajarkan secara bertahap. Pada mulanya cukup dengan puluhan satuan dulu baru berikutnya meningkat secara bertahap. 
$\mathrm{Hal}: 72-84$

Berdasarkan latar belakang diatas tujuan penelitian ini membahas mengenai bagaimana penguasaan 4 (empat) prasyarat dasar aritmatika yang meliputi kemampuan membilang, membuat barisan bilangan Aritmatika/kelipatan, komplemen terutama Sembilan dan sepuluh, dan konsep nilai tempat pada bilangan mempengaruhi kemampuan siswa dalam menyelesaikan soal matematika yang terdiri atas penjumlahan, pengurangan, perkalian, dan perkalian.

\section{Metode Penelitian}

Metode penelitian adalah cara alamiah untuk memperoleh data dengan kegunaan dan tujuan tertentu [9]. Pendekatan dalam penelitian ini menggunakan pendekatan deskriptif, pendekatan tersebut dimaksudkan untuk memaparkan atau menggambarkan pemahaman tentang penguasaan aritmatika dasar terhadap kemampuan menyelesaikan soal matematika terkait penjumlahan, pengurangan, perkalian dan pembagian serta bagaimana antara penguasaan aritmatika dasar dan kemampuan menyelesaikan soal matematika mempunyai hubungan dan pengaruh. Dalam penelitian ini metode yang digunakan adalah metode kombinasi antara kualitatif dan kuantitatif. Pendekatan kualitatif digunakan untuk mendeskripsikan tentang penguasaan aritmatika dasar siswa meliputi kemampuan membilang, membuat barisan bilangan Aritmatika/kelipatan, komplemen terutama Sembilan dan sepuluh, dan konsep nilai tempat pada bilangan. Adapun pendekatan kuantitatif menggunakan uji statistic dengan analisis korelasi kanonikal untuk menjawab tentang hubungan dan pengaruh antara pemahamant entang penguasaan aritmatika dasar terhadap kemampuan menyelesaikan soal matematika terkait penjumlahan, pengurangan, perkalian dan pembagian.

Dalam penelitian ini metode yang digunakan adalah eksperimen. Frenkel et al. (2012) mengatatakan, bahwa "Experimental research is one of the most powerful research methodologies that researchers can use. Of the many types of research that might be used, the experiment is the best way to establish cause-and-effect relationships among variables" [10]. Secara umum, karakteristik penelitian eksperimen dalam penelitian ini meliputi:

1. Manipulasi

2. Pengendalian atau kontrol

3. Pengamatan

Setelah perlakuan diberikan selama kurun waktu tertentu, peneliti melakukan pengamatan atau pengukuran untuk mengetahui pengaruh dari manipulasi/perlakuan yang diberikan terhadap variabel yang diteliti. Pengamatan dilakukan melalui pengumpulan data berupa tes.

\section{Desain Penelitian}

Desain penelitian adalah keseluruhan dari perencanaan untuk menjawab pertanyaan penelitian dan mengantisipasi beberapa kesulitan yang mungkin timbul selama proses penelitian. Hal ini penting karena desain penelitian merupakan strategi untuk mendapatkan data yang dibutuhkan untuk keperluan pengujian hipotesis atau untuk menjawab pertanyaan penelitian, dan sebagai alat untuk mengontrol variabel yang berpengaruh dalam penelitian [11].

Berikut desain kualitatif yang akan digunakan dalam penelitian ini 


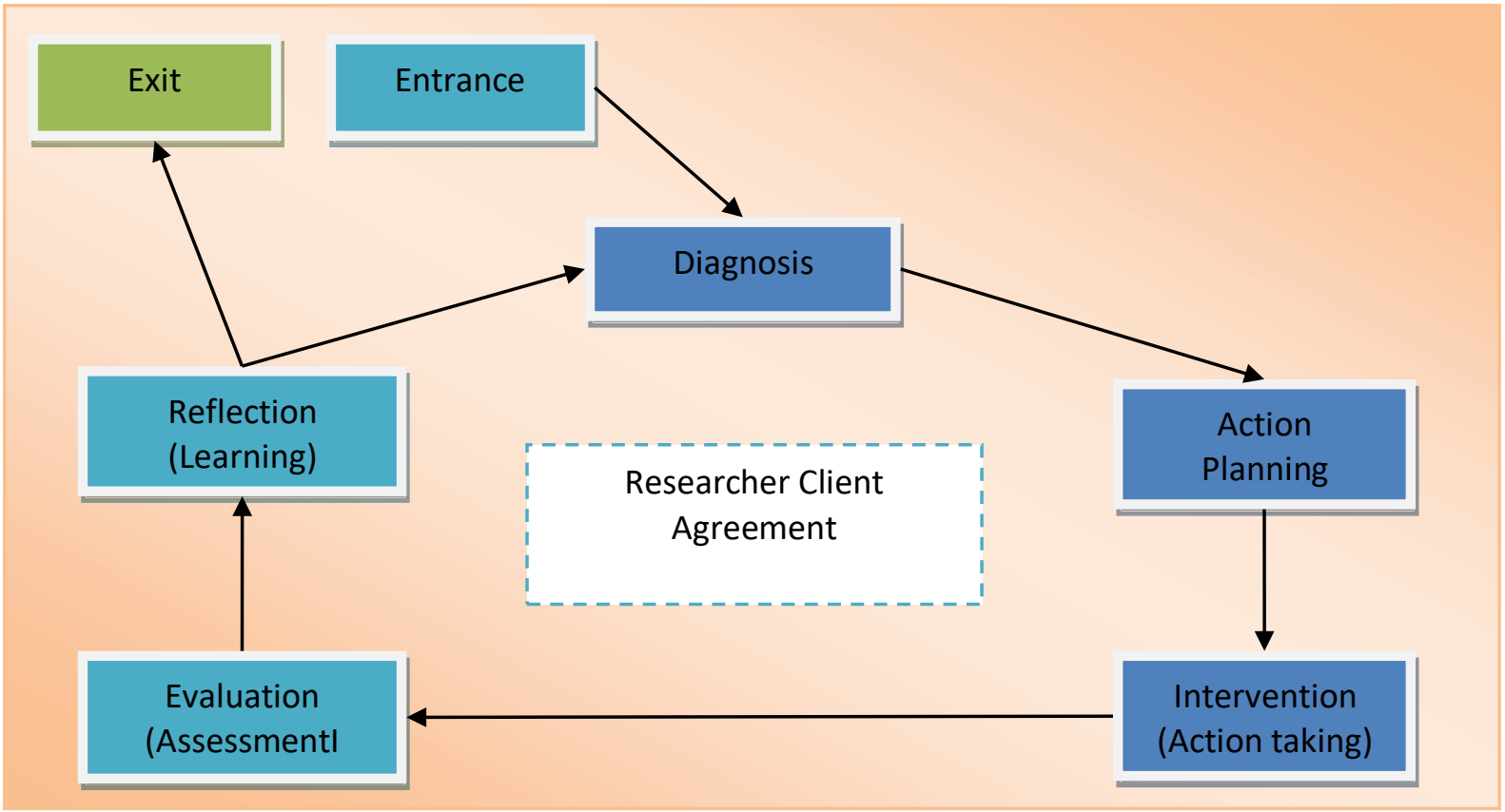

Gambar 1. Desain Penelitian Kualitatif

Sumber: diolahpeneliti

Entrance dalam penelitian ini adalah kemampuan menyelesaikan soal matematika terkait penjumlahan, pengurangan, perkalian dan perkalian yang masih rendah. Kemudian, peneliti melakukan identifikasi masalah untuk dapat mendiagnosis kemampuan yang masih kurang yang dialami siswa dalam menyelesaikan soal matematika. Pada tahap diagnosis ini, peneliti melakukan wawancara langsung kepada siswa untuk dapat mengetahui kesulitan apa yang dialami serta apa saja faktor penyebabnya. Setelah diketahui kesulitan dan faktor penyebabnya, peneliti menyusun suatu rencana tindakan (action planning) untuk mengatasi kesulitan tersebut, peneliti merencanakan membuat eksperimen penguasaan aritmatika dasar meliputi kemampuan membilang, membuat barisan bilangan Aritmatika/kelipatan, komplemen terutama Sembilan dan sepuluh, dan konsep nilai tempat pada bilangan. Rencana yang telah disusun tersebut kemudian diterapkan.

Setelah pembelajaran dengan model tersebutdilaksanakan, selanjutnya peneliti melakukan evaluasi/assessment. Evaluasi yang dilakukan bukan hanya dengan memberikan tes, melainkan juga dengan melakukan observasi terhadap pembelajaran. Keseluruhan hasil evaluasi, kemudian direfleksi (refleksi/learning) dengan melihat kelebihan dan kekurangan model pembelajaran dalam mengatasi kemampuan menyelesaikan soal matematika yang tergolong rendah. Jika hasil refleksi menunjukkan ,bahwa masih terjadi kesulitan pada siswa, maka penelitian dilanjutkan kembali mengikuti tahapan-tahapan sebelumnya sehingga membentuk suatu siklus. Siklus berakhir jika hasil pada refleksi siklus terakhir menunjukkan, bahwa kesulitan siswa sudah teratasi atau kemampuan siswa dalam menyelesaikan soal matematika meningkat sesuai dengan yang seharusnya (exit).

Sedangkan desain kuantitatif yang akan digunakan dalam penelitian ini berupa desain penelitian eksperimen The One-Shot Case Study Design. Desain ini digunakan karena dalam penelitian ini terdapat suatukelompok yang diberiperlakuan (treatment), dan selanjutnya diobservasi hasilnya. Perlakuan (treatment) sebagai variabel independent dan hasil yang diobervasi sebagai variabel dependen. Teknik sampling yang digunakan untuk desain ini adalah purposive sampling. 


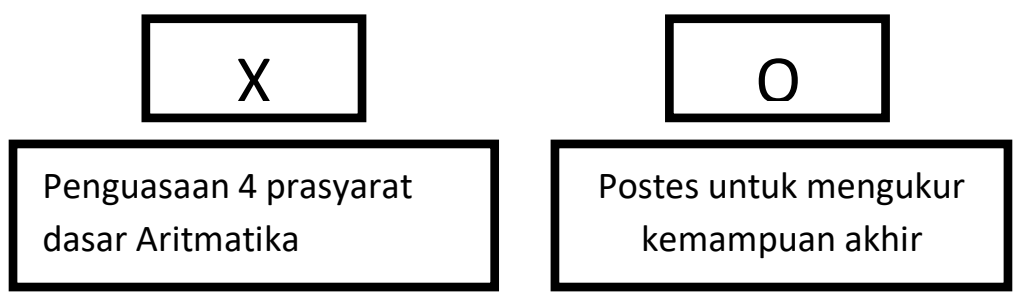

\section{Gambar 2. The One-Shot Case Study Design}

Keterangan:

$\mathrm{X}=$ perlakuan/treatment yang diberikan (variabel independent)

$\mathrm{O}=$ postes (variabel dependen yang diobservasi)

Teknik sampling yang digunakan untuk desain ini adalah purposive sampling. Purposive sampling adalah teknik penentuan sampel dengan pertimbangan tertentu. Pertimbangan dalam mengambil sampling adalah penelitian dimaksudkan khusus untuk meneliti mahasiswa jurusan IImu Komunikasi Universitas Peradaban untuk matakuliah Sistem Politik Indonesia.

Teknik Analisis Data

Penulis melakukan analisis data dengan menggunakan analisis uji statistic korelasi kanonikal. Analisis korelasi kanonikal merupakan model statistic multivariat yang digunakan untuk menguji hubungan (korelasi) antara lebih dari satu set variabel dependen dan lebih dari satu set variabel independent. Pada analisis regresi berganda kita hanya memprediksi satu variabel dependen dengan lebih dari satu set variabel independent, sementara itu korelasi kanonikal secara simultan memprediksi lebih dari satu variabel dependen dengan lebih dari satu variabel independen.Berikut ini ilustrasi analisis korelasi kanonikal

Tabel 1. Ilustrasianalisiskorelasikanonikal

\begin{tabular}{ll}
\hline KemampuanMenyelesaikanSoalMatematika & PenguasaanAritmatika Dasar \\
\hline 1. Penjumlahan & 1. Kemampuanmembilang \\
2. Pengurangan & 2. Membuatbarisanbilangankelipatan \\
3. Perkalian & 3. Komplemen Sembilan dan sepuluh \\
4. Pembagian & 4. Konsepnilaitempat pada bilangan
\end{tabular}

\begin{tabular}{lll}
\hline KompositVariabelDependen & $\begin{array}{l}\text { Canonical } \\
\text { Correlation }\end{array}$ & KompositVariabellndependen \\
Dependent canonical variate & & Independent canonical variate \\
\hline
\end{tabular}

Sumber: penulis

Dua variabel dependen akan dibuat menjadi satu komposit Dependent canonical variate dan dua variabel independent akan dibuat menjadi komposist Independent canonical variatte. Korelasi kanonikal (Rc) akan mengukur kuatnya hubungan antara dua set multiple variabel (canonical variatets). Canonical variate menggambarkan kombinasi linear optimal antara variabel dependen dan independent, sedangkan canonical correlation (Rc) menggambarkan kuatnya hubungan antar kedua variabel tersebut.

Tujuan analisis korelasi kanonikal dalam penelitian ini berupa:

- Menentukan apakah dua set variabel tidak berhubungan satu sama lainnya (independent) atau sebaliknya menentukan besarnya/kuatnya hubungan antara dua set variabel tersebut.

- Menentukan nilai tertimbang dari masing-masing set variabel dependen dan independent sehingga di dapat kombinasi linear dari set variabel yang memberikan korelasi maksimum.

- Menjelaskan sifat hubungan bila ada antara set variabel dependen dan set variabel independent, umumnya diukur dengan kontribusi relative darimasing-masing variabel terhadap fungsi kanonikalnya. 
Hal : $72-84$

\section{Hasil Penelitian dan Pembahasan}

\section{Penguasaan 4 Prasyarat Dasar Aritmatika}

\section{Kemampuan Membilang}

Kemampuan membilang adalah jurus dasar yang paling sederhana. Untuk tahap awal ajarkan anak membilang bilangan mulaidari 0 sampai 10. Yang ideal adalah 0 sampai 18, tetapi untuk tahap awal membilang 0 sampai 10 sudah cukup baik. Ini bisa dilakukan dengan mudah misalnya dengan memakai jari tangan atau benda apapun misalnya koin, permen, kelereng atau benda apapun. Sebelum jari dibuka berarti nol, jari dibuka satu buah, anak membilang satu. Jari dibuka lagi satu buah sehingga ada dua jari terbuka, anak membilang dua, dan seterusnya. Ini bisa dilakukan dengan benda apapun. Akan lebih baik jika memakai variasi berbagai macam benda. Misalnya berapa jumlah kelereng dalam tabung? Keluarkan semua kelereng dalam tabung. Tunjukkan bahwa kaleng tadinya kosong berarti jumlah kelereng mula-mula $=$ nol. Lalu masukkan satu kelereng sembari membilang satu, masukkan lagi satu kelereng sambil membilang dua, masukkan lagi kelereng berikutnya sambil membilang tiga, dan seterusnya sampai semua kelereng dimasukkan dalam tabung sesuai dengan jumlah kelereng.

Kemudian contohnya dapat diganti benda lain, misalnya uang logam. Berapa jumlah uang logam dalam kotak? Sebelum ada uang logam atau saat kotak masih kosong berarti nol, kemudian uang logam dimasukkan anak mulai membilang satu, uang logamd imasukkan lagi, anak membilangd ua dan seterusnya sampai uang logam selesai dimasukkan dan anak mendapatkan berapa jumlah uang logam. Lakukan cara seperti ini dengan benda-benda lain.

Ajarkan anakmembilang maju sampai anak bisa membilang dengan lancar dari 0 sampai 10 . Nol, satu, dua, tiga, empat, lima, enam, tujuh, delapan, Sembilan, sepuluh. Biarkan anak membilang dengan bersuara dengan lafal yang cukup jelas. Berikut ilustrasi yang digunakan dalam belajar membilang:
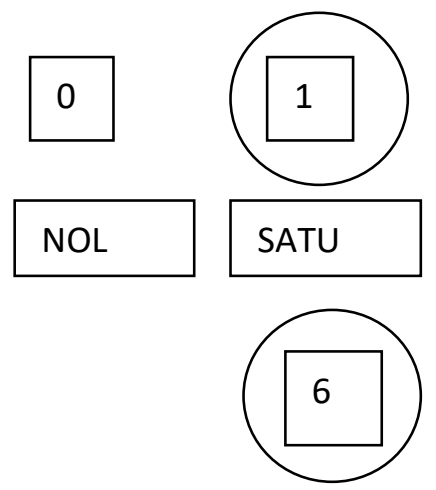

ENAM
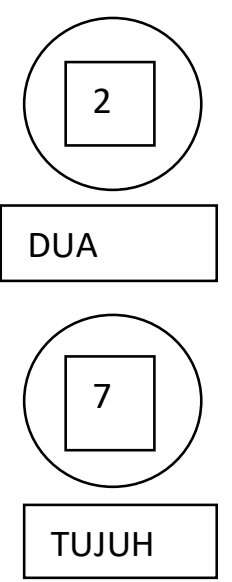
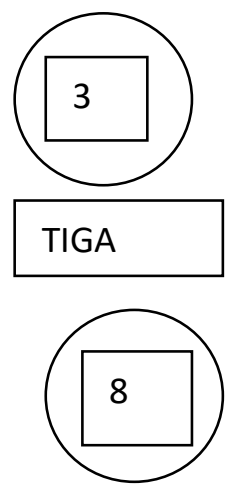

DELAPAN
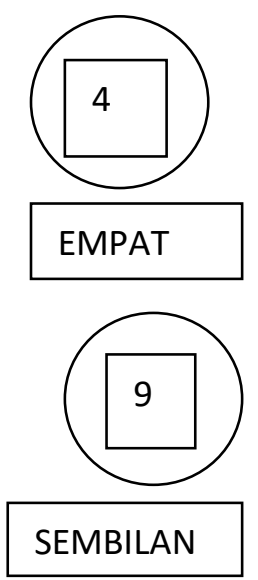

Gambar 3.llustrasi Belajar Membilang

Apabila anak telah lancar membilang maju, ajak anak bermain-main membilang mundur. Secara alamiah membilang maju lebih mudah, karena itu boleh juga jika anak diajarkan membilang maju yang lebih besar misalnya sampai 50 tetapi tidak harus selalu dimulai dengan nol atau satu karena akan melelahkan jika selalu membilang mulai dari 1 sampai 50 . Misalnya saja kadang-kadang membilang mulai 20 sampai 30 . Kadang-kadang mulai 30 sampai 50 . Ini dilakukan agar tidak terlalu melelahkan dan malah membuat bosan.

\section{Barisan Bilangan/Kelipatan}

Setelah anak cukup lancar membilang, ajarkan anak membilang kelipatan dengan model lompat kodok. Misalnya loncat dua: 2, 4, 6, 8, 10, 12. Loncat tiga misalnya 3, 6, 9, 12, 15. Anda bisa melakukan ini dengan menampilkan barisan bilangan cacah ata uasli (bilangan muldai dari nol atau satu) kemudian melingkari angka-angka yang dilompati kodok sesuai panjang loncatan kodok. Bila 
$\mathrm{Hal}: 72-84$

perlu buat alat peraga bergambar kodok. Biarkan anak anda bersenang-senang dengankodoknya. Buatlah pertanyaan yang melatih daya nalar anak, misalnya:

"Apabila kodok "singgah" di angka 2 kemudian kodok tadi melompat "singgah" di angka 4, selanjutnya kodok tadi "singgah" ke angka berapa?" Enam Pak." Setelah enam lalu berapa Budi?" Delapan, Pak." "lya...pinter..."

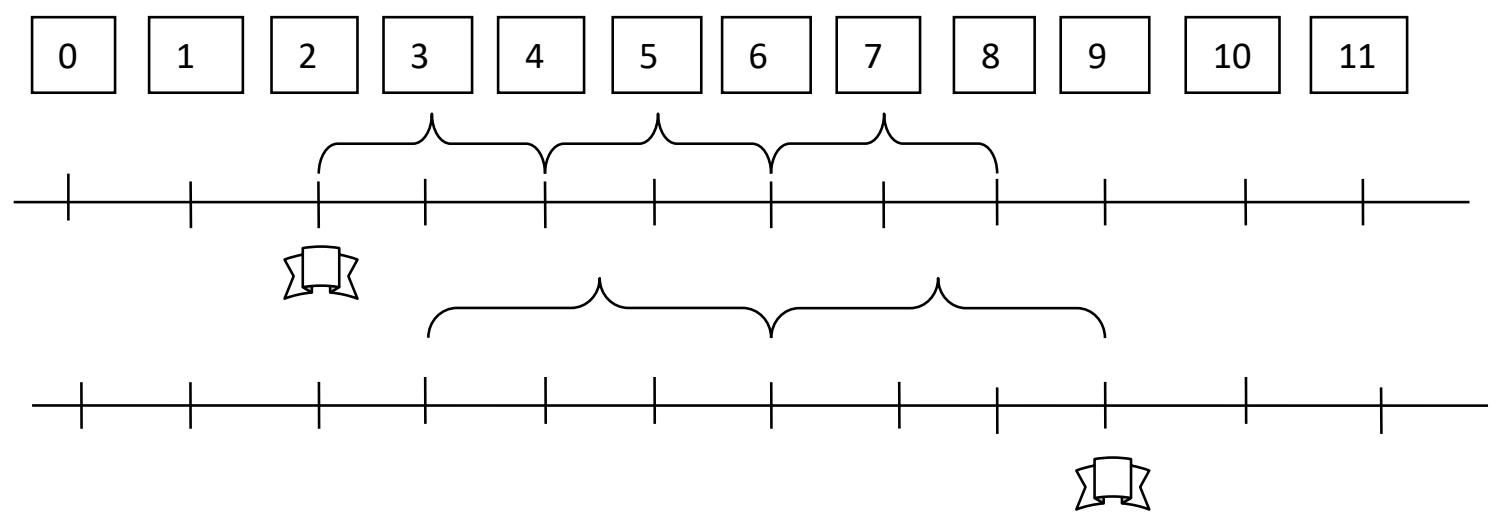

Gambar 4. Ilustrasi Belajar Kelipatan

Gambar 4 merupakan ilustrasi belajar kelipatan yang dapat digunakan untuk mempermudah pembelajaran. Setelah anak mahir membuat loncat kodok, sekarang buatlah tantangan sehingga anak bisa membilang barisan bilangan lompat-lompat tanpa bantuan gambar kodok dan garis bilangan. Apabila anak mengalami kesulitan mencari berapa angka berikutnya, ajarilah anak anda mempraktikan jurus pertamanya untuk membantu menghitung. Misalnya setelah 3 , lalu 6 . Anak bisa membilang maju dimulai dari angka setelah tiga. Teriakkan angka tiga lalu mulai membilang maju mulai angka empat sembari membuka satu jari, lalu buka lagi satu jari sembari mengatakan lima, buka lagi satu jari sembari mengatakan lima, buka lagi satu jari sembari mengatakan enam. Oke kita sudah mendapatkan angka enam. Anak membilang 4, 5, 6 dan akan mendapatkan tiga jarinya terbuka. Jadi untuk menemukan angka berikutnya anak perlu membilang maju sebanyak tiga kali juga. Teriakkan angka 6 lalu mulai membilang dengan membuka jaridu mulai dengan angka tujuh kemudian delapan dan Sembilan. Jadi setelah 3 dan 6 adalah 9. Demikian seterusnya.

Komplemen Sembilan dan Sepuluh

Komplemen Sembilan adalah dua bilangan bulat satuan yang apabila dijumlahkan hasilnya Sembilan. Misalnya saja 2 dan 7 karena $2+7=9$. Mialnya lagi 3 dan 6 karena $3+6=9$. Komplemen sepuluh adalah duabilangan bulatsatuan yang apabila dijumlahkan hasilnya sepuluh. Misalnya saja 4 dan 6 karena $4+6=10$. Misalnya 3 dan 7 karena $3+7=10$.

Mengapa yang dibahas adalah komplemen Sembilan dan sepuluh bukan komplemen yang lain? Silakan saja apabila anak diajarkan komplemen yang lain, memang itu juga baik. Tetapi menurut penulis, di antara komplemen yang lain, komplemen terpenting yang sebaiknya diajarkan adalah komplemen sembilan dan sepuluh. Komplemen Sembilan penting karena Sembilan adalah angka satuan terbesar dan memiliki sifat-sifat yang cukup istimewa. Beberapa kasus perkalian misalnya perkalian istimewa angka Sembilan, juga bisadihitung dengan mudah apabila ana kterampil memakaikomplemen Sembilan. Komplemen sepuluh juga penting karena perhitungan standar yang kita lakukan adalah memakai basis sepuluh. Penerapanpraktiskomplemen Sembilan dan sepuluh baru terasa ketika anak mulai "beneran" belajar operasi matematika. 
$\mathrm{Hal}: 72-84$

Tabel 2.Komplemen Sembilan dan Sepuluh

\begin{tabular}{|c|c|}
\hline \multicolumn{2}{|c|}{ Komplemen 9 } \\
\hline 0 & 9 \\
\hline 1 & 8 \\
\hline 2 & 7 \\
\hline 3 & 6 \\
\hline 4 & 5 \\
\hline 5 & 4 \\
\hline 6 & 3 \\
\hline 7 & 2 \\
\hline 8 & 1 \\
\hline 9 & 0 \\
\hline
\end{tabular}

\begin{tabular}{|c|c|}
\hline \multicolumn{2}{|c|}{ Komplemen 10 } \\
\hline \multicolumn{2}{|c|}{} \\
\hline 2 & 9 \\
\hline 3 & 8 \\
\hline 4 & 7 \\
\hline 5 & 6 \\
\hline 6 & 5 \\
\hline 7 & 4 \\
\hline 8 & 3 \\
\hline 9 & 2 \\
\hline
\end{tabular}

Mengapa pasangan 0 dan 10 tidak ditulis di atas? Karena 9 adalah angka satuan terbesar. Bilangan 10 terdiri atas dua angka yaitu 1 dan 0 yang masing-masing sudah berbeda nilai tempatnya. Umumnya pasangan 10 dan 0 jarang dipakai karena perkalian dengan 10 atau kelipatannya mudah dikerjakan karena angka belakangnya nol. Untuk mengajarkan anak mengerti pasangan bilangan di atas caranya cukup mudah. Misalnya anda ingin mengajarkan anak komplemen 9 (Sembilan). Ambilah 9 (Sembilan) buah benda misalnya Sembilan koin logam. Lalu ambillah beberapa koin di antara Sembilan koin tersebut. Mintalah anak anda menghitung koin yang anda ambil dan koin yang tersisa. Dengan cara ini anak mengerti pasangan bilangan yang apabila dijumlahkan akan membentuk Sembilan. Misalnyadari Sembilan koin itu diambil tiga akan tersisa enam. Misalnya dari Sembilan koin diambil dua maka tersisa tujuh dan sebagainya
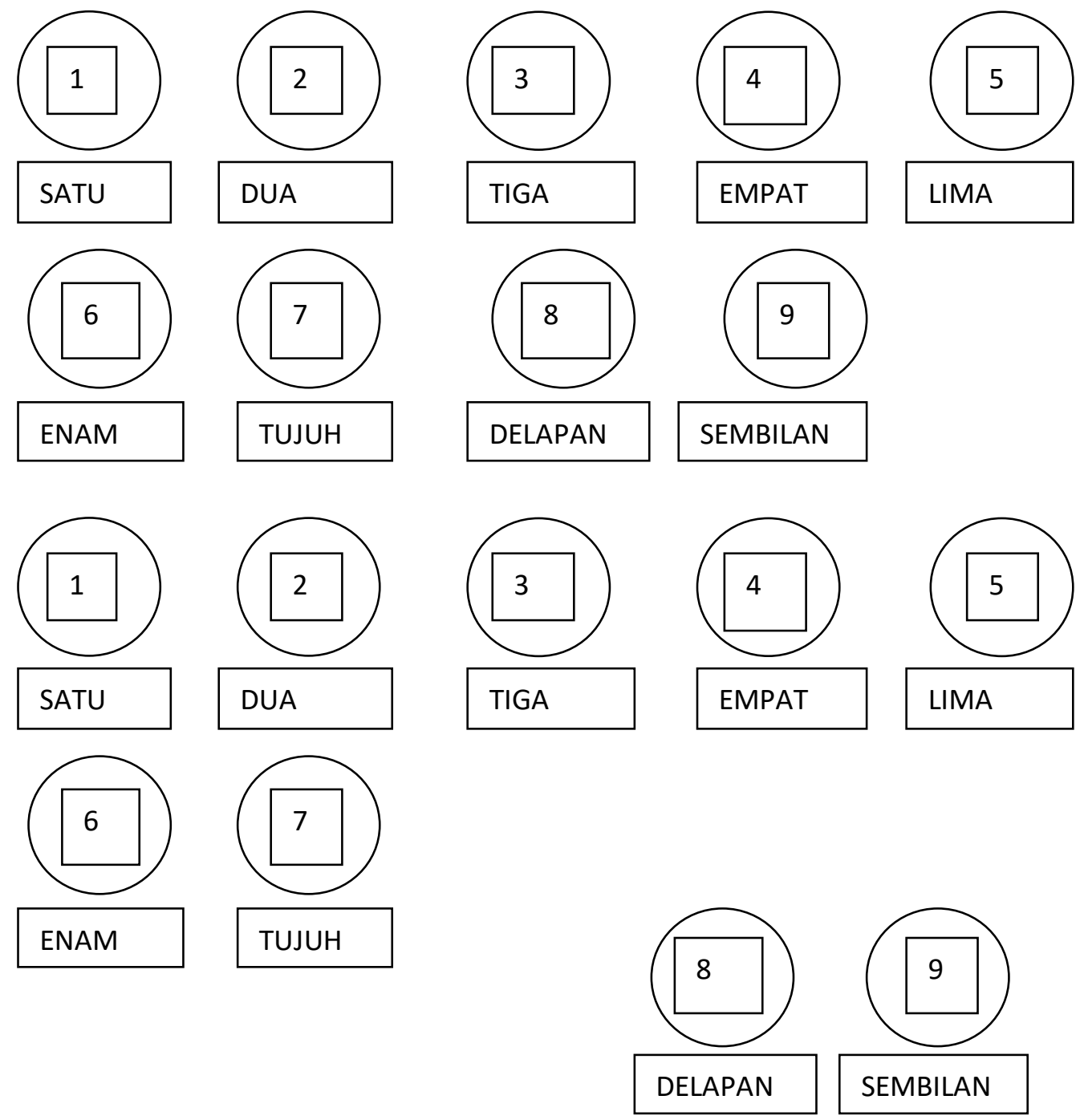

Endro Tri Susdarwono

Penguasaan 4 (Empat) Prasyarat Dasar Aritmatika untuk Meningkatkan Kemampuan Siswa Sekolah Dasar dalam Menyelesaikan Soal Matematika 
Gambar 5.IllustrasiBelajarKomplemen

Lakukan cara yang sama untuk mengajarkan anak komplemen sepuluh. Anda tinggal menambah satukoin sehingga ada sepuluh koin, lalu pisahkan koin tersebut menjadi duabagian. Misalnyabagian yang satu berjumlah dua koin, maka sisanya delapan koin, dan sebagainya. Komplemenataujumlahpembentukbilangan sebenarnya bukan cuma Sembilan atau sepuluhsajatetapisebagaidasar, komplemen Sembilan dan sepuluh sudahcukup. Komplemen sebenarnya bisa juga berbentuk pasangan positif negative misalnya komplemen 10 adalah 11 (sebelas) dan -1 (negatifsatu). Ini bisa diajarkan secara bertahap. Untuk tahap awal komplemen pasangan positif sudah cukup.

\section{Nilai Tempat pada Bilangan}

Setiap angka pada bilangan memiliki nilai yang berbeda, selain dari angkanya juga terkait dengan perbedaan nilai tempatnya. Misalnya anggap saja kita memiliki dua buah bilangan. Bilangan pertama adalah 7234. Bilangan kedua adalah 99782. Angka 2 (dua) pada masing-masing bilangan berbeda nilainya karena letaknya berbeda. Angka dua pada 7234 karena terletak pada nilai tempat ratusan maka identik dengan 200 sedangkan angka dua pada 99782 karena terletak pada nilai tempat satuan maka sama dengan dua.

Satuan bertempat pada bagian paling kanan. Angka yang ada pada nilai tempat satuan identik dengan dikalikan satu atau sama dengan nilai angka itusendiri. Puluhan berada di sebelah kiri satuan. Angka yang ada pada kolom atau nilaitempatpuluhan identic dengan dikalikan sepuluh. Ratusan berada di sebelah kiri puluhan. Angka yang ada pada kolom ratusan identik dengan dikalikan seratus.

Untuk mempermudah anak memahami ini bisa digunakan alat bantu misalnya koin logam. Ambillah sejumlah koin misalnya 32 buah koin. Hitung jumlah kointersebut dengan cara membilang satu demi satu Bersama-samasehinggaanakmendapatkan bahwajumlahkointersebuttigapuluhdua. Katakan kepada anak: "Koin tersebut akan dikelompokkan sepuluh sepuluh." Masukkan tiap sepuluhkoinkedalamplastikkecil. Maka akan kita dapatkan ada 3 (tiga) bungkusan koin dalam plastik, masing-masing berisi 10 koin dan sisanya ada 2 (dua) koin.

Setiap bungkusan karena masing-masing berisi sepuluh koin disebut puluhan. Sedangkan koin yang tidak dibungkus adalah satuan. 1 (satu) puluhannilainyaadalh 10 (sepuluh) satuan, karena masing-masing bungkus isinya 10 koin. Apabila setiap sepuluh buah bungkusan puluhan kita bungkus lagi dengan plastik yang lebihbesar, maka kita akan mendapatkan bungkusan ratusan. 1 (ratusan) nilainya setarad engan 10 (sepuluh) puluhan, setara juga dengan 100 (serratus) satuan.

Dari peragaan tersebut bisa diketahui, misalnya saja:

- 32 adalah identik dengan $3 \times 10+2 \times 1$ atau $3 \times 10+2$.

- 3 buahbungkusanmasing-masingberisi 10 koinditambahsisanyayaitu 2 .

- 32 identikdengan 3 puluhan +2 satuan.

- 56 dalahidentikdengan $5 \times 10+6$

- 56 identikdengan 5 puluhan +6 satuan

Tabel 3 llustrasi Belajar Nilai Tempat

\begin{tabular}{l|l|l|l|}
\multicolumn{1}{|c}{ Puluhan } & Satuan \\
\hline 32 & 3 & 2 & $=30+2$ \\
\hline 56 & 5 & 6 & $=50+6$ \\
\hline
\end{tabular}

- 225 identikdengan $2 \times 100+2 \times 10+5$

- 225 identikdengan 2 ratusan +2 puluhan +5 satuan

- 156 identikdengan $1 \times 100+5 \times 10+6$

- 156 identikdengan 1 ratusan +5 puluhan +6 stuan 
$\mathrm{Hal}: 72-84$

Tabel 4. Ilustrasi Belajar Nilai Tempat

\begin{tabular}{|c|c|c|c|c|}
\multicolumn{1}{c}{ Ratusan } & Puluhan & \multicolumn{1}{c|}{ Satuan } \\
\hline 225 & 2 & 2 & 5 & $=200+20+5$ \\
\hline 156 & 1 & 5 & 6 & $=100+50+6$ \\
\hline
\end{tabular}

Paling kanan adalah kolom satuan di sebelah kiri satuan adalah kolom puluhan. Di sebelah kiri puluhan adalah kolom ratusan.

Dari siniterlihat pada 225 angka dua didepan lebih besar nilainya dari angka dua ditengah karena angka dua di depan setara dengan 200 karena berada pada kolom ratusan. Sedangkan angka dua di tengah setara dengan 20 karena ada pada kolom puluhan.

Angka yang berada paling kanan adalah satuan. Jadi paling kanan adalah nilait empat satuan. Di sebelah kiri dari satuan adalah puluhan, disebelah kiri puluhan adalah ratusan. Kemudian ribuan, demikian seterusnya. Apabila anak belum tahu perkalian cukup diiajarkan bahwa apabila ada dua bungkus masing-masing isinya 10 (sepuluh) maka total semua koin adalah 20 (duapuluh). 20 adalah $10+10$ atau 10 nya ada dua kali. Pemahaman konsep dasar ini berguna bahkan sampai mahasiswa.

\section{Hubungan Penguasaan Aritmatika Dasar Terhadap Kemampuan Menyelesaikan Soal Matematika}

Fungsi kanonikal yang akan dianalisis adalah fungsi yang memberikan koefisien korelasi kanonikal yang signifikan secara statistic. Jika fungsi kanonikal lainnya tidak signifikan, maka hubungan antara variabel tidak akan diinterpretasikan. Fungsi kanonikal mana yang akan diinterpretasikan dilihat dari tiga kriteria: (1) tingkat signifikansi dari fungsi kanonikal, (2) besaran nilai korelasi kanonikal dan (3) redundancy ukuran untuk prosentase variance yang dijelaskan oleh dua data set.

Jika tiga kriteria diatas telah dipenuhi, maka langkah berikutnya adalah menginterpretasikan hasil fungsi kanonikal. Interpretasi dilakukan dengan menganalisis fungsi kanonikal untuk menentukan pengtingnya masing-masing variabel awal (original) didalam hubungan kanonikal. Ada tiga metode yang dapat digunakan yaitu: (1) canonical weight (standardized coefficients), (2) canonical loading (structure correlations), dan (3) canonical cross loading.

Design 1 EFFECT ...WITHIN CELLS Regression Multivariate Tests of Significance $(S=2, M=3, N$ $=1 / 2)$

Tabel 5. Analysis of Variance

\begin{tabular}{|c|c|c|c|c|c|}
\hline Test Name & Value & Approx. F & Hypoth. DF & Error DF & Sig. of F \\
\hline Pillais & 1.45350 & .71348 & 16.00 & 20.00 & .751 \\
\hline Hotellings & 725.91879 & 22.68496 & 16.00 & 2.00 & .043 \\
\hline Wilks & .00081 & 3.90544 & 16.00 & 6.75 & .040 \\
\hline Roys & .99862 & & & & \\
\hline
\end{tabular}

Note.. F statistic for WILKS' Lambda is exact.

Sumber: diolahpenulis

Table anova di atas memberikan uji signifikansi alternative. Biasanya yang digunakan adalah wilks lambda yang menguji signifikansi dari korelasi kanonikal pertama. Hasil uji signifikansi ternyata dua uji statistik menunjukkan signifikan pada 0,05 utamanya adalah uji wilks lambda. Jadi dapat disimpulkan bahwa korelasi kanonikal pertama signifikan. Jika korelasi kanonikal pertama tidak signifikan, maka korelasi kanonikal kedua dan seterusnya juga tidak signifikan.

Tabel 6. Eigenvalues and Canonical Correlations

\begin{tabular}{|l|l|l|l|l|l|}
\hline Root No. & Eigenvalue & Pct. & Cum. Pct. & Canon Cor. & Sq. Cor \\
\hline 1 & 725.30659 & 99.91566 & 99.91566 & .99931 & .99862 \\
\hline 2 & .42975 & .05920 & 99.97486 & .54825 & .30057 \\
\hline 3 & .18246 & .02514 & 100.00000 & .39282 & .15431 \\
\hline
\end{tabular}

Sumber: diolahpenulis 
$\mathrm{Hal}: 72-84$

Tabel 7. Dimension Reduction Analysis

\begin{tabular}{|l|l|l|l|l|l|}
\hline Roots & Wilks L. & F & Hypoth. DF & Error DF & Sig. of F \\
\hline 1 TO 4 & .00081 & 3.90544 & 16.00 & 6.75 & .040 \\
\hline 2 TO 4 & .59150 & .19938 & 9.00 & 7.45 & .986 \\
\hline 3 TO 4 & .84569 & .17482 & 4.00 & 8.00 & .945 \\
\hline 4 To 4 & 1.00000 & .00000 & 1.00 & 5.00 & 1.000 \\
\hline
\end{tabular}

Sumber: diolahpenulis

Di dalam model kita terdapat empat variabel dependen dan empat variabel independent. Jika kita ambil jumlah terkecil yaitu dua variabel dependen, maka akan terbentuk dua fungsi kanonikal. Dua fungsi kanonikal ini terlihat pada Root No dengan angka korelasi kanonikal (Canon Cor) untuk fungsi 1 adalah 0,99931, fungsi 2 adalah 0.54825, fungsi 3 adalah 0.39282 dan fungsi 4 adalah 0,00000. Korelasi kanonikal pertama lebih penting dari korelasi kanonikal yang lainnya. Untuk korelasi kanonikal pertama, "covariate" variabel kanonikal mampu menjelaskan 99,86\% variasi dalam variabel canonical dependen. Sedangkan korelasi kanonikal kedua, ketiga, keempat menjelaskan variasi berturut-turut sebesar 30,08\%, 15,43\%, 0\%. Oleh karena korelasi kanonikal kedua, ketiga, keempat menjelaskan variasi yang rendah maka selanjutnya tidak kita analisis dan yang dianalisis hanya fungsi pertama.

Jika dilihat pada kolom signifikan yang menguji fungsi kanonikal terlihat untuk fungsi 1 signifikan pada 0,040. Oleh karena fungsi 1 memiliki signifikansi di bawah 0,05 maka dapat diproses lebih lanjut. Dengan batas 0,5 untuk kekuatan korelasi dua variabel, maka fungsi 1 mempunyai korelasi kanonikal di atas 0,5. Dengan demikian fungsi tersebut dapat dianalisis lebih lanjut.

Setelah diketahui fungsi kanonikal 1 signifikan langkah selanjutnya adalah melakukan interpretasi terhadap canonical variate yang ada pada fungsi 1. Canonical variate adalah kumpulan dari beberapa variabel yang membentuk sebuah variate. Dalam kasus kita ada dua canonical variates, yaitu dependent canonical variates yang berisi empat variabel $X 5, X 6, X 7$, dan $X 8$, serta independent canonical variates, yang berisi empat variabel independent $X 1, X 2, X 3$, dan X4. Analisis pada prinsipnya ingin mengetahui apakah semua variabel independent dalam canonical variate tersebut berhubungan erat dengan dependen variate, yang diukur dengan besaran korelasi masing-masing independent variabel dengan variatenya.

Pengukuran canonical variates dapat dilakukan dengan melihat canonical weight atau canonical loading.

Tabel 8. Canonical Weight Standardized canonical coefficients for DEPENDENT variables Function No.

\begin{tabular}{|l|l|}
\hline Variable & 1 \\
\hline X5 & -.52331 \\
\hline X6 & .86147 \\
\hline X7 & .54086 \\
\hline X8 & .20188 \\
\hline
\end{tabular}

Standardized canonical coefficients for COVARIATES

CAN. VAR.

\begin{tabular}{|l|l|}
\hline COVARIATE & 1 \\
\hline $\mathrm{X} 1$ & .19345 \\
\hline $\mathrm{X} 2$ & .05141 \\
\hline $\mathrm{X} 3$ & .70522 \\
\hline $\mathrm{X} 4$ & .36172 \\
\hline
\end{tabular}

Sumber: diolahpenulis

Untuk Fungsi 1 pada dependen variabel terdapat tiga angka korelasi tinggi dan di atas 0,5 yaitu $0,52331,0,86147$, dan 0,54086 sedangkan untuk variabel independent (covariate) angka korelasi di atas 0,5 hanya ada satu variabel X3. 
$\mathrm{Hal}: 72-84$

Tabel 9. Canonical Loading Correlations between DEPENDENT and canonical variables Function No.

\begin{tabular}{|l|l|}
\hline Variable & 1 \\
\hline X5 & .44256 \\
\hline X6 & .88185 \\
\hline X7 & .85106 \\
\hline X8 & .05757 \\
\hline
\end{tabular}

Correlations between COVARIATES and canonical variables

CAN. VAR.

\begin{tabular}{|l|l|}
\hline COVARIATE & 1 \\
\hline $\mathrm{X} 1$ & .70647 \\
\hline $\mathrm{X} 2$ & .66375 \\
\hline $\mathrm{X} 3$ & .94253 \\
\hline $\mathrm{X} 4$ & .45482 \\
\hline
\end{tabular}

Sumber: diolahpenulis

Untuk fungsi 1 dependen variabel memberikan dua angka canonical loading sama tingginya karena di atas 0,5 yaitu X6 dengan loading 0,882 dan X7 dengan loading 0,851. Sedangkan untuk variabel independent (covariates) angka loading di atas 0,5 adatigayaitu X1 dengan loading $0,706, X 2$ dengan loading 0,664, dan X3 dengan loading 0,943.

\section{Kesimpulan}

Dari hasil canonical weight maupun canonical loading fungsi 1 dapat disimpulkan memang terdapat hubungan signifikan antara dependent variate dengan independent variate atau penguasaan aritmatika dasar dan kemampuan siswa dalam mengerjakan soal matematika memang berkorelasi secara bersama-sama dengan X1 (kemampuan membilang), X2 (kelipatan), X3 (komplemen Sembilan dan sepuluh), dan X4 (konsep nilai tempat pada bilangan). Namun dari keempat variabel independent ini ada tiga yang mempunyai kaitan erat yaitu X1 (kemampuan membilang), X2 (kelipatan), dan X3 (komplemen sembilan dan sepuluh). Tanda positif pada variabel X1, X2, dan X3 berarti semakin tinggi kemampuan membilang, kemampuan kelipatan, dan kemampuan komplemen Sembilan dan dan sepuluh semakin tinggi kemampuan siswa dalam menyelesaikan soal matematika terkait penjumlahan, pengurangan, perkalian dan pembagian.

\section{Daftar Pustaka}

[1] Dila, Oki Ratna \&Zanthy, Luvy Sylviana, 2020. Identifikasi Kesulitan Siswa dalam Menyelesaikan Soal Aritmatika Sosial. Teorema: Teori dan RisetMatematika, [e-jurnal ]5(1), pp.17-26.

[2] Nurhayati, Yanti et al., 2020. Integrasi Contextual Teaching Learning (CTL) dengan Geogebra:Dapatkah Meningkatkan Kemampuan Koneksi Matematis Siswa?. Teorema: Teori dan RisetMatematika, , [e-jurnal] 5(1), pp.27-34.

[3] Prasetya, J. T., \& Ahmadi, A., 2015. Strategi belajar mengajar. Bandung: CV.

[4] Arni, Nanda Cintya, 2019. Profil Berpikir Metaforis Siswa SMP Dalam Memecahkan Masalah Matematika Ditinjau Dari Gaya Kognitif. Soulmath: JurnallImiahEdukasiMatematika, [e-jurnal ]7(2), pp.85-96.

[5] Fatimah, A. T. \& Zakiah, N. E., 2018. Kelancaran prosedural matematis dalam pemecahan masalah konteks pemasaran. Mathline:Jurnal Matematika dan Pendidikan Matematika, [e-jurnal] 3(2), pp.141-150.

[6] Russeffendi, E., 2006.Pengantar Kepada Membantu Guru Mengembangkan Kompetensinya Dalam Pengajaran Matematika Untuk Meningkatkan CBSA. Bandung: Tarsito.

[7] Afgani, J.D., 2011. Analisis Kurikulum Matematika. Jakarta:Universitas Terbuka

[8] Arryawan, Eko, 2011. Matematika Yin Yang: JurusHitung Sakti dari Barat dan Timur. Jakarta: PT Elex Media Komputindo.

[9] Lestari, Karunia Eka \& Yudhanegara, Mokhammad Ridwan, 2015. Penelitian Pendidikan Matematika. Bandung: PT Refika Aditama. 
Hal : $72-84$

[10] Fraenkel, J.R., Wallen, N.E., \& Hyun, H.H., 2012. How to Design and Evaluate Research in Education. United States (New York): McGraw-Hill Companies. Inc.

[11] Sugiyono, 2010. Metode Penelitian Bisnis (Pendekatan Kuantitatif, Kualitatid dan R\&D). Bandung: Alfa 